\title{
Endoscopic Vacuum Therapy for Esophageal Perforation Treatment after Foreign Body Ingestion: Resolution after a Single Session
}

\author{
Rui Morais Filipe Vilas-Boas Marco Silva Pedro Pereira Guilherme Macedo \\ Gastroenterology Department, Hospital de São João, Porto, Portugal
}

Keywords

Esophageal perforation · Foreign body · Endoscopic vacuum therapy

Terapêutica endoscópica de vácuo para perfuração esofágica após ingestão de corpo estranho: resolução após uma única sessão

\section{Palavras Chave}

Perfuração esofágica · Corpo estranho · Terapêutica endoscópica de vácuo

A 70-year-old man was admitted to the Emergency Department due to chest pain after foreign body ingestion (chicken bone) 5 days before. He mentioned having fever but denied other symptoms. Chest computed tomography (CT) scan revealed in the thoracic esophagus, in the same plane as the left atrium, a linear and dense object $30 \mathrm{~mm}$ in size, with signs of esophageal perforation and presence of an adjacent collection $(23 \times 31$ $\times 61 \mathrm{~mm}$ ) (Fig. 1). Following multidisciplinary discussion, it was decided to remove the foreign body and close the esophageal defect endoscopically. Upper endo-

\section{KARGER}

karger@karger.com www.karger.com/pjg
(C) 2019 Sociedade Portuguesa de Gastrenterologia Published by S. Karger AG, Basel

Karger

Upen access

This article is licensed under the Creative Commons AttributionNonCommercial-NoDerivatives 4.0 International License (CC BYNC-ND) (http://www.karger.com/Services/OpenAccessLicense). Usage and distribution for commercial purposes as well as any distribution of modified material requires written permission. scopy was performed (online suppl. Video; see www. karger.com/doi/10.1159/000503011) and confirmed the presence of a bone penetrating the esophageal wall, 32 $\mathrm{cm}$ from the incisors (Fig. 2). The surrounding mucosa was congestive, and purulent drainage was noticed. The foreign body was removed using an alligator jaw grasping forceps, and a 5-mm esophageal wall defect was observed (Fig. 3). We decided to perform endoscopic vacuum therapy (EVT) to try to close the defect and simultaneously treat the collection. The sponge (Endo-Sponge system, B. Braun, Melsungen, Germany) was placed in the esophageal lumen after appropriate positioning of the overtube (Fig. 4). After the procedure, the patient was admitted on total parenteral nutrition, antibiotics, and an antifungal. Five days later, upper endoscopy was repeated with sponge removal. Granulation tissue was observed at the location of the wall defect, with apparent resolution of the perforation (Fig. 5). CT was repeated showing no oral contrast leakage and significant improvement of the collection dimensions $(27 \times 17 \mathrm{~mm})$. The patient resumed oral feeding 2 days after sponge removal, completed a 10-day antibiotic course, and was discharged. He remains well 9 months after the procedure, with no esophageal symptoms. 


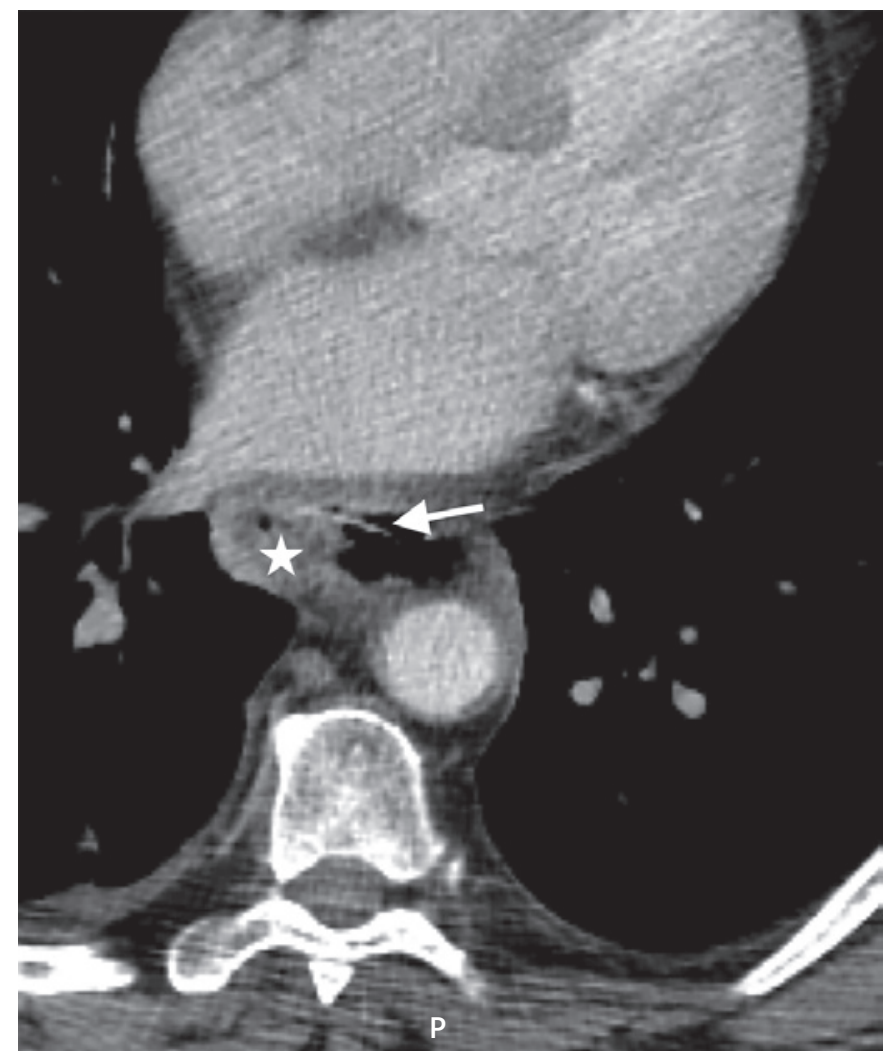

Fig. 1. Axial view of chest CT scan revealing in the thoracic esophagus, in the same plane as the left atrium, a linear and dense object $30 \mathrm{~mm}$ in size (arrow), with signs of esophageal perforation and presence of an adjacent collection $(23 \times 31 \times 61 \mathrm{~mm})$ (star).

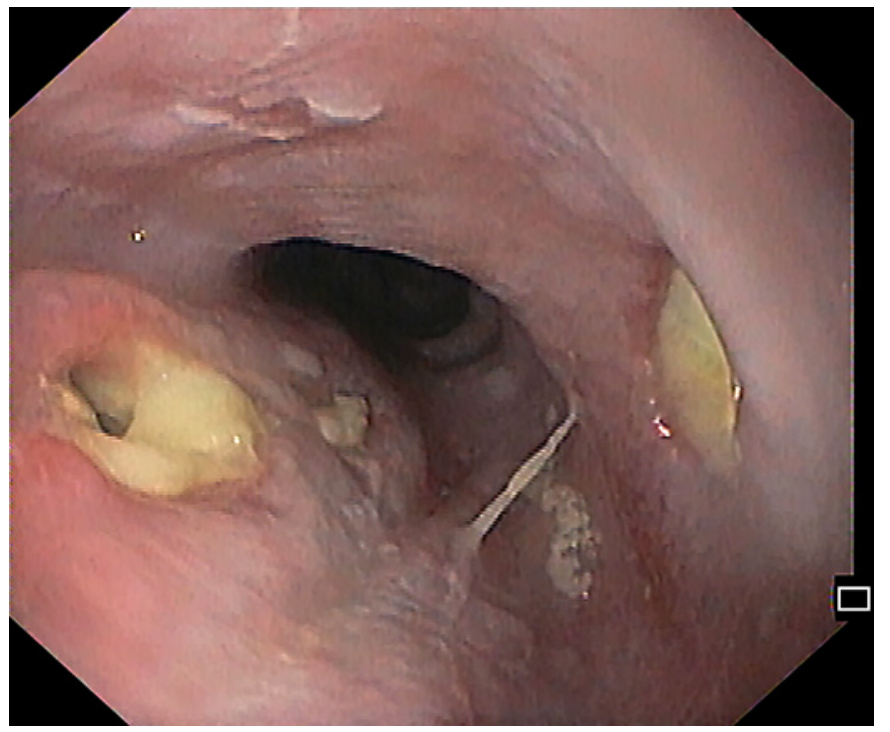

Fig. 3. Esophageal perforation was observed after foreign body removal.
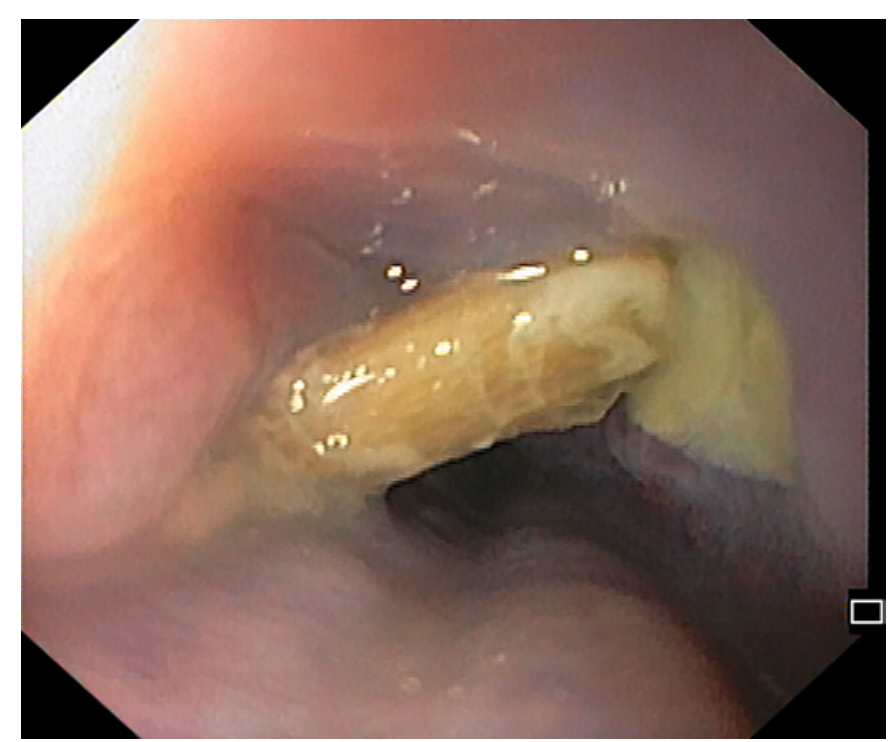

Fig. 2. Upper endoscopy confirming the presence of a bone penetrating the esophageal wall.

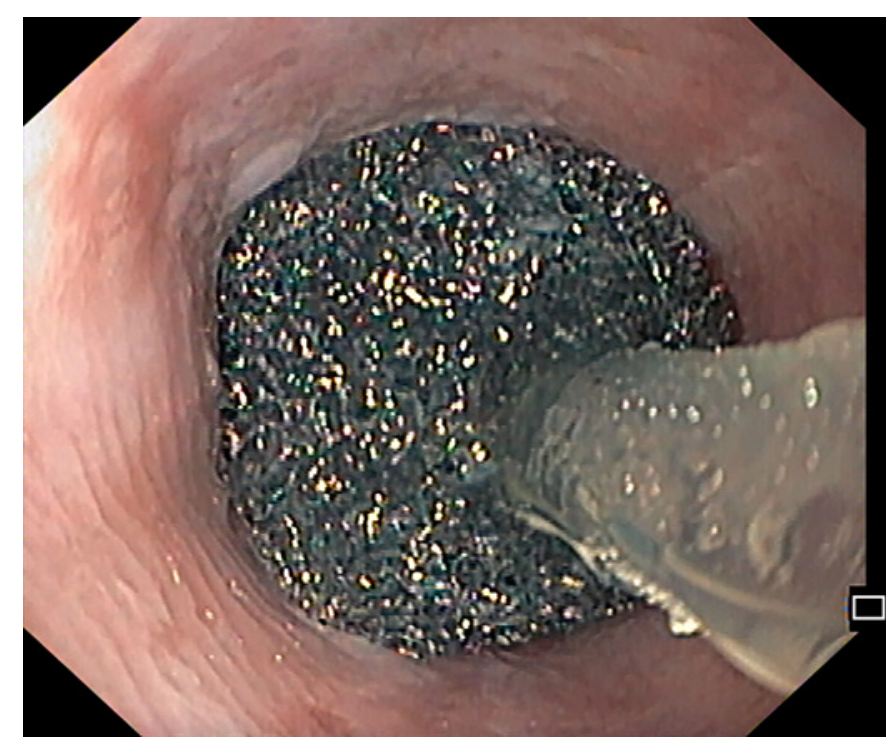

Fig. 4. Endoscopic vacuum therapy was performed, with sponge placement in the esophageal lumen. 


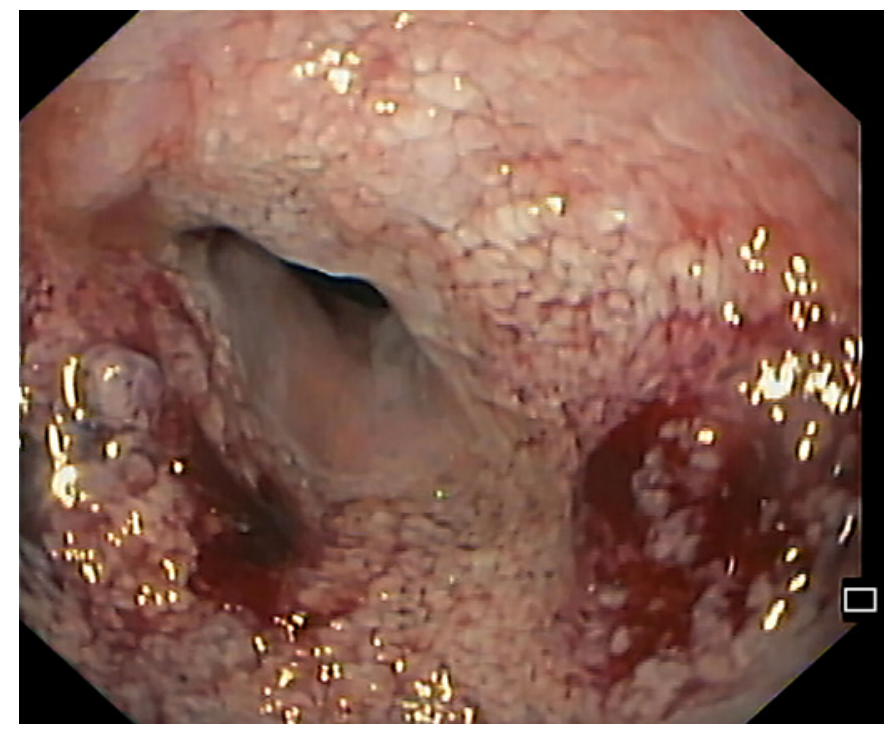

Fig.5. Complete closure of the esophageal perforation was achieved after 1 session of endoscopic vacuum therapy.

Esophageal perforations are rare, with an incidence of 3.1 per 1,000,000 per year [1] but are associated with high morbidity and mortality $[2,3]$. Although surgery has traditionally been the gold standard care for patients with esophageal perforation, endoscopy is now emerging as the primary treatment modality of this condition [4]. Endoscopic closure of esophageal transmural defects can be achieved using a variety of modalities, including throughthe-scope clips, over-the-scope clips, stents, or endoscopic suturing; however, additional percutaneous/surgical drainage of collections is often required [5]. EVT is an alternative approach for the endoscopic treatment of esophageal perforations, allowing simultaneous closure of the defect and drainage of a collection [6,7]. Previous studies have evaluated the role of EVT in the treatment of esophageal perforations, with a reported successful closure of the defect between 70 and $100 \%$, with an average of 5 sponge exchanges (range $0-39$ ) [8-11]. In this case, only 1 EVT session was necessary, with no need for sponge replacement, highlighting the efficacy of this technique for treating esophageal wall defects with associated collections.

\section{Statement of Ethics}

The authors have no ethical conflicts to disclose.

\section{Disclosure Statement}

The authors have no conflicts of interest to declare.

\section{References}

1 Vidarsdottir $\mathrm{H}$, Blondal S, Alfredsson $\mathrm{H}$, Geirsson A, Gudbjartsson T. Oesophageal perforations in Iceland: a whole population study on incidence, aetiology and surgical outcome. Thorac Cardiovasc Surg. 2010 Dec; 58(8):476-80.

2 Altorjay A, Kiss J, Vörös A, Bohák A. Nonoperative management of esophageal perforations. Is it justified? Ann Surg. 1997 Apr; 225(4):415-21.

3 Bufkin BL, Miller JI Jr, Mansour KA. Esophageal perforation: emphasis on management. Ann Thorac Surg. 1996 May;61(5):1447-51.

4 Saxena P, Khashab MA. Endoscopic Management of Esophageal Perforations: Who, When, and How? Curr Treat Options Gastroenterol. 2017 Mar;15(1):35-45.
5 Rodrigues-Pinto E, Morais R, Macedo G, Khashab MA. Choosing the Appropriate Endoscopic Armamentarium for Treatment of Anastomotic Leaks. Am J Gastroenterol. 2019 Mar;114(3):367-71.

6 Laukoetter MG, Mennigen R, Neumann PA, Dhayat S, Horst G, Palmes D, et al. Successful closure of defects in the upper gastrointestinal tract by endoscopic vacuum therapy (EVT): a prospective cohort study. Surg Endosc. 2017 Jun;31(6):2687-96.

7 de Moura DT, de Moura BF, Manfredi MA, Hathorn KE, Bazarbashi AN, Ribeiro IB, et al. Role of endoscopic vacuum therapy in the management of gastrointestinal transmural defects. World J Gastrointest Endosc. 2019 May;11(5):329-44.
8 Möschler O, Nies C, Mueller MK. Endoscopic vacuum therapy for esophageal perforations and leakages. Endosc Int Open. 2015 Dec;3(6):E554-8.

9 Kuehn F, Schiffmann L, Janisch F, Schwandner F, Alsfasser G, Gock M, et al. Surgical Endoscopic Vacuum Therapy for Defects of the Upper Gastrointestinal Tract. J Gastrointest Surg. 2016 Feb;20(2):237-43.

10 Loske G, Schorsch T, Dahm C, Martens E, Müller C. Iatrogenic perforation of esophagus successfully treated with Endoscopic Vacuum Therapy (EVT). Endosc Int Open. 2015 Dec; 3(6):E547-51.

11 Heits N, Stapel L, Reichert B, Schafmayer C, Schniewind B, Becker T, et al. Endoscopic endoluminal vacuum therapy in esophageal perforation. Ann Thorac Surg. 2014 Mar;97(3): 1029-35. 